\section{Annals of Spiru Haret University \\ Economic Series \\ Since 2000 \\ ISSN: 2393-1795 ISSN-L:2068-6900}

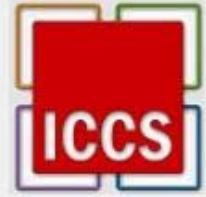

Issue $2 / 2016$

\title{
STRATEGIC APPROACH TO SUPPLY CHAIN MANAGEMENT IN LOGISTICS
}

\author{
Alexandru BURDA ${ }^{1}$, Sebastian CHIRIMBU ${ }^{2}$ \\ ${ }^{1}$ Faculty of Tourism and Trade Management, "Dimitrie Cantemir" \\ Christian University, 76 Splaiul Unirii, sector 4, Bucharest, Romania, \\ Email: alex.burda@mail.com \\ 2"Spiru Haret" University, Ion Ghica Street, no. 13, Bucharest, 030045, \\ Romania, Tel.: +40214551000, Fax: +40213143900; \\ Wells University, Bucharest, Romania/ IOSUD Doctoral School - \\ Valahia University, Târgovişte, Romania, \\ Email: sebastianchirimbu@yahoo.com
}

\begin{abstract}
According to its mission, the fundamental purpose of logistics is to contribute to the achievement of customer services in terms of efficiency. Company's performance in the supply chain is given by the delivery service. It must be established from the way the company responds to every order received from the customer as a result of implementing a strategy consisting of a series of specific decisions. A higher level of service requires those decisions to permit the firm to meet an optimal service level and a complete customer satisfaction in terms of price, time value of the invoice, goods arrived safely at their destination. The level at which an order is satisfied is a measure of the performance of the supply chain of the company and of the strategy applied by the company for its management.
\end{abstract}

Key words: logistics; supply chain; strategy; customer; performance.

JEL Classification: L11 


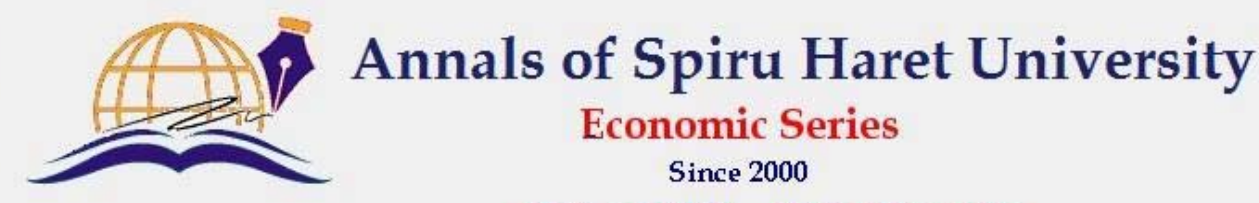

ISSN: 2393-1795 ISSN-L:2068-6900

\section{Issue 2/2016}

\section{Introduction}

According to its mission, the fundamental purpose of logistics is to contribute to the achievement of a maximum customer services in terms of efficiency. To achieve this, the logistics department and the company management must take account of (1) the need to know the customers' requirements on service level and the ability of the firm of cater, (2) the need to know the level of service offered by competitors, and (3) the ability of the firm, compared to the competition, to provide the level of service required by the customers [Lambert et al., 1998]. The analysis of these three aspects of management allows a company to identify the weaknesses and strengths of its business as the possible opportunities and threats in the market.

\section{Literature Review}

At present many authors are speaking more often about the important role of the logistics specialist in ensuring the competitiveness of the organization. Also authors are speaking more frequently about the concept of logistics in the trade activity in goods. Although it is a term originally used for military (army on the movement and supply), later on it has expanded into the economic activity and in other areas.

However, logistics is still interpreted in many different ways both by practitioners, specifically those carrying out economic activities (commercial or production) and by specialists, economic theorists and researchers in the field. This situation makes logistics to be misunderstood or in any case different to understand, from case to case, its conceptual significance.

The tendency is to consider mainly the operational component of logistics rather than the strategic one. Consequently, the interpretation of the way logistics establishes the link between production and distribution networks through its transversal component within companies is also limited and not always correct.

\section{Theoretical Background}

At the same time, it must be taken into account that each market or customer group is characterized by its own set of needs [Radu, 2013]. Some markets require and pay for a high level of readiness (as short delivery 


\section{An Annals of Spiru Haret University \\ Economic Series \\ Since 2000 \\ ISSN: 2393-1795}

ISSN-L:2068-6900

Issue $2 / 2016$

times, the acceptance of higher costs). Other markets call for efficiency (costs as low as possible, despite longer delivery times). The strategy of a company in general and especially the logistics strategy, as well as the action plans to achieve its objectives, must be based on the customer's requests and the ability of the company to respond to them.

Because the logistic strategy of a company has to be based on its customers' needs, the supply chain used by a company must provide the appropriate (optimal) combination between customer requests related to a promptly delivery and those related with efficiency in the delivery of products and goods. A company whose supply chain better meets the needs of its customers will gain market share at the expense of other companies in the market and will thus be more profitable.

\section{Types of Supply Chain Management Decisions}

The participants in a supply chain constantly take decisions that affect the way in which their activities are conducted. Each organization tries to maximize results through a combination of outsourcing, partnership and conducting its own activities. At the moment the tendency is to focus on key competencies outside the firm and obtaining other activities needed to run the company [Radu, 2013]. Although each supply chain has its unique set of market demands and operating modes, problems to be solved remain the same in every situation. Therefore, in each supply chain, management and specialists in logistics need to take individual and collective decisions relating to (1) production, (2) storage, (3) establishing production sites, (4) transport and (5) information management.

Production (1) must include production scheduling, according to factory production capacity, balancing the required work effort, quality control, equipment maintenance. Decisions will be based on the nature of the products the market requests, the required quantities and the required timeframe for delivery.

Storage (2) must be used in order to insure a "buffer" against insecurity in the supply chain. Specific decisions regard determining the size of stocks on each level of the supply chain, the size of inventories of raw materials, semi-finished and finished products, and the optimal inventory size and timing of launching a new command. All these decisions must be always based on implicit costs. 


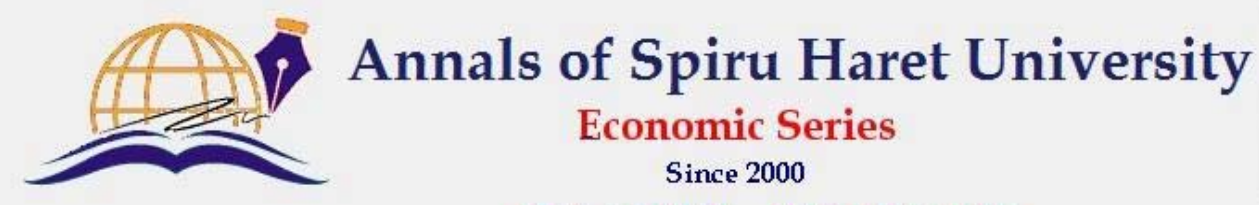

ISSN: 2393-1795 ISSN-L:2068-6900

\section{Issue 2/2016}

Production location setting (3) must include decisions related to the location of factories and warehouses, the establishment of locations that involve the lowest cost, i.e. to determine whether to use existing sites or build new ones. Once taken these types of decisions, the available paths for the product to reach the final consumer are determined.

Transport (4) will involve decisions about moving inventory from one location to another within a supply chain, namely the opportunity of using different modes of transport. Thus, the distribution by air transport means or by truck can be faster and reliable, but also more expensive. Water transport or train are less expensive, but usually involve a period of time and are less certain. This uncertainty may be compensated by a higher level of inventories.

Information management (5) will require from a company decisions on the establishment of the necessary information, i.e. the information provided by the company to its partners in the supply chain. Timely and accurate information ensures proper coordination and making better decisions. With high quality information, those involved have the ability to make correct decisions about the necessary production, size and location of stocks and finding better transport solutions.

The sum of all decisions at this five areas' level defines the effectiveness and efficiency of the supply chain. The way a company can act and the ways it can compete in the market heavily dependent on the efficiency and effectiveness of the supply chain.

\section{Adapting the Supply Chain to Achieve the Strategic Objectives of the Company}

As shown, each market or customer category is characterized by its own set of needs. The various supply chains that serve these markets must address those needs. Some markets call and pay for a high level of readiness. Other markets require that their chains to focus on efficiency. The effect of all decisions of the five areas of the supply chain will determine how well it serves the market and how profitable is that chain for its participants [Radu, 2013]. 


\section{Annals of Spiru Haret University \\ Economic Series \\ Since 2000 \\ ISSN: 2393-1795 ISSN-L:2068-6900}

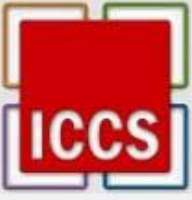

Issue $2 / 2016$

Thus, if a company's strategy is to sell products in large quantities at a low price, supply chain must be optimized so as the obtaining and/or the distribution of products to achieve the lowest possible costs. Conversely, if a company's strategy is to respond to requests from a particular segment of the market with the competitive advantage of the high level of customer service, supply chain must be optimized to meet their needs promptly.

To adapt the supply chain to enable it to reach the strategic objectives of the company, it is necessary to (1) understand the markets served by the company, (2) define strengths, skills that distinguish the company and its role in serving customers and (3) develop the supply chain capabilities to support the way the company acts [Radu, 2013].

Understanding the markets served by the company (1) involves establishing the typology of own customers, the typology of the customers' clients, the type of supply chain the company is part of and the types of needs that customers have.

Regarding the types of needs that customers may have, it should be determined:

- the quantities requested by customers: those focused on timeliness and/or proximity prefer small quantities and those who want a lower price are usually buying in bulk;

- the delivery times requested by customers: residential customers in general are less willing to accept delivery delays (even if they are not necessarily long) compared to corporate customers;

- the customer-requested product categories: high-value products (that satisfy higher value needs) are required in smaller quantities than those of lower value (satisfying the primary needs);

- the delivery service level requested: complete and timely delivery or gradual deliver on longer term;

- the price accepted by the customer: customers seeking short delivery times are willing to accept higher prices;

- the pace of product innovation: customers seeking a fast pace of innovation are willing to accept higher prices for the goods but they are calling for short delivery deadlines instead. 


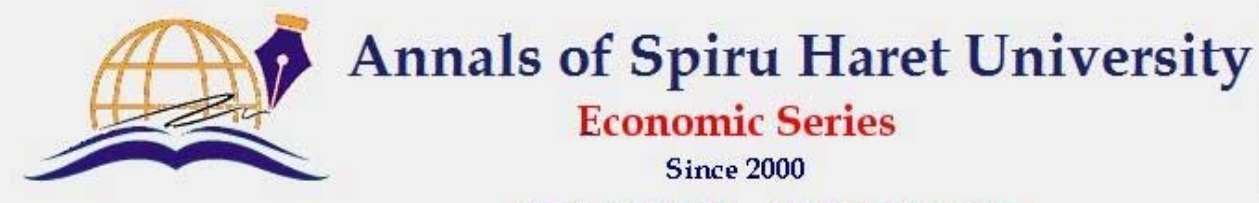

ISSN: 2393-1795 ISSN-L:2068-6900

\section{Issue 2/2016}

Defining competencies and distinctive roles of the company (2) involves establishing the company's position in the supply chain (as manufacturing company, as wholesale or retail distributors, as service providers, etc.), setting out key skills and the main source of profit. Establishing these issues must be made carefully because the company can serve several different market segments and can be part of many supply chains. If serving multiple market segments, the company must still seek ways to benefit from its distinctive competencies. Some parts of the supply chain can only belong to a distinctive market segment served, while others can be combined to achieve economies of scale.

For example, if manufacturing is a distinctive competence of a company, it can produce a wide range of different products in the same factories. Then the various storage and transport options can be used to deliver products to different market segments.

Capacity building-delivery supply chain (3) is based on decisions made regarding five areas. Thus, through production, delivery timeliness can be achieved by building factories with large reserves of production capacity and/or using flexible manufacturing techniques that will produce a variety of products. For an even better delivery timeliness, a company can produce in several smaller plants, close to the target customers.

Efficiency through production can be obtained by using plants with very low capacity reserves, which are optimized for producing a low range of products, to reduce costs. A greater efficiency can be achieved by centralizing production in large power plants that will produce economies of scale.

Through storage, delivery timeliness can be achieved with higher inventories, for a wide range of products. An even better delivery timeliness can be obtain by storing products in multiple locations, so they are either close to their customers or available immediately.

Efficiency can be achieved by reducing the size of inventories for all goods and especially for those that sell less frequently. Economies of scale can also be achieved by storing goods in a few central warehouses.

Through the production units' site, delivery timeliness can be achieved by opening more outlets/retail points, physically close to the customer base (e.g., fast food restaurants). Conversely, to get efficiency, fewer locations that centralize all activities are needed. 


\section{An Annals of Spiru Haret University \\ Economic Series \\ Since 2000 \\ ISSN: 2393-1795 \\ ISSN-L:2068-6900}

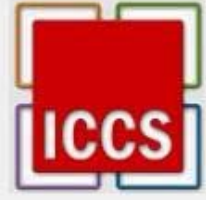

Issue $2 / 2016$

Through transport, delivery timeliness can be achieved by the choice of means of transport that are fast and flexible (such as aviation). In turn, efficiency can be gained by postponing delivery until transport means are loaded to maximum capacity. In this instance it is also preferable to use cheaper means of transport (water, rail or pipeline). Transport is even more effective if it starts from a single central point and not from several different locations.

Through information, a company can achieve a high level of delivery readiness by collecting and transmitting accurate and timely data generated by operations. But when it comes to focusing on efficiency, companies should prefer less information related to fewer activities. Also, sometimes companies choose to send less information about them in order not to be exposed to the risk of that information being used against them.

\section{Conclusion}

Company's performance in the supply chain is given by the delivery service. It must be established from the way the company responds to every order received from the customer as a result of implementing a strategy consisting of a series of specific decisions. A higher level of service requires those decisions to permit the firm to meet an optimal service level and a complete customer satisfaction in terms of price, time value of the invoice, goods arrived safely at their destination. The level at which an order is satisfied is a measure of the performance of the supply chain of the company and of the strategy applied by the company for its management.

\section{References}

1. Ackerman, Kenneth B., "Value-Added Warehousing Cuts Inventory Costs", Transportation and Distribution, (July1989): 32-35.

2. Bălan, Carmen, Logistica. Ediția a III-a revăzută şi adăugită (București: Editura Uranus, 2006).

3. Ballou, Ronald H., Business Logistics Management. Third Edition. Englewood Cliffs (New Jersey: Prentice-Hall International, Inc., 1992). 

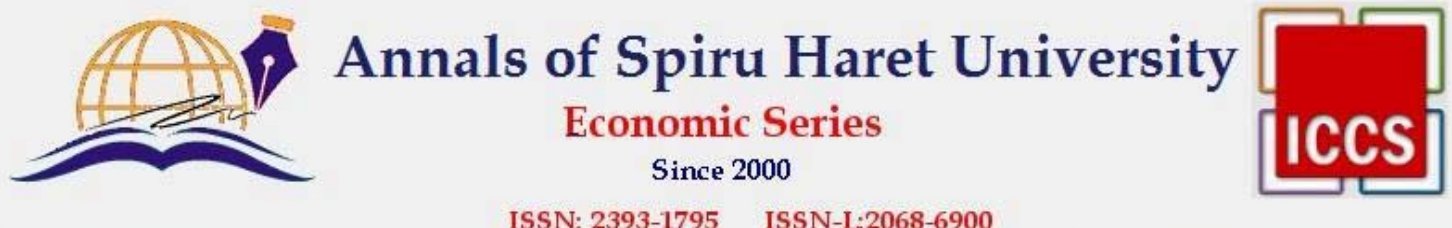

ISSN: 2393-1795 ISSN-L:2068-6900

\section{Issue 2/2016}

4. Bowersox, Donald J. et al., "Ten Mega-Trends that Will Revolutionize Supply Chain Logistics", Journal of Business Logistics, Council of Logistics Management, Vol. 21, No. 2 (2000).

5. Burda, Alexandru, Logistica şi distribuția mărfurilor, Ediția a IV-a (Bucureşti: Editura Pro Universitaria, 2014).

6. Cătăneț, Alina, Aprovizionarea (I). Logistică: Modul 2 (Bucureşti, Editura Eurocor, 2013).

7. Cătăneț, Alina, Transportul mărfurilor. Logistică: Modul 4 (București, Editura Eurocor, 2013).

8. Christopher, Martin, Developing Customer Service Strategies, fourth edition (Surrey: Gower Publishing Company Ltd., 1990)

9. Ellram, Lisa, „The Supplier Selection Decision in Strategic Partnerships”, Journal of Purchasing and Materials Management (Fall 1990): 8-14.

10. Gattorna, John, The Gower Handbook of Logistics and Distribution Management (Editor John Gattorna, Gower Publishing Company Ltd., 1990).

11. Ghiani, G. et al., Introduction to Logistics Systems Planning and Control (London: John Wiley \& Sons Ltd., 2004).

12. Jenkins, M.L., „Utilizing Public Warehouses”, Plants, Sites and Parks (November-December 1992).

13. Lambert, Douglas M. and Stock, James R., Strategic Logistics Management, 3rd edition (Editor Richard D. Irwin, Burr Ridge, Illinois, 1993).

14. Lambert, Douglas M. et al. Fundamentals of Logistics Management (Editor Irwin McGraw-Hill, New York: McGraw-Hill Higher Education, 1998).

15. Radu, Cătălina, Aprovizionarea (II). Logistică: Modul 3 (București: Editura Eurocor, 2013).

16. Radu, Cătălina, Specialistul în logistică. Logistică: Modul 1 (Bucureşti: Editura Eurocor, 2006). 